\title{
Er selvrapportert fysisk aktivitet egnet til å belyse helsevirkninger av lett fysisk aktivitet?
}

\author{
Victoria Telle Hjellset og Arne T. Høstmark \\ Institutt for helse og samfunn, Universitetet i Oslo \\ Korrespondanse: Victoria Telle Hjellset, Institutt for helse og samfunn, Universitetet i Oslo, Postboks 1130 Blindern, 0318 Oslo \\ E-mail: v.t.hjellset@medisin.uio.no Telefon: +4722 858281
}

\begin{abstract}
SAMMENDRAG
Fysisk aktivitet kan redusere risikoen for flere kroniske sykdommer, og kan vurderes ved bruk av spørreskjema, eller måles objektivt. I en undersøkelse blant innvandrerkvinner fra Pakistan $(n=86)$ har vi sammenlignet selvrapportert (International Physical Activity Questionnaire, IPAQ) og objektivt målt fysisk aktivitet (SenseWear Armband). For å sikre at kvinnene forsto hva det ble spurt om ble det benyttet prosjektmedarbeidere fra Pakistan og India som hjalp deltakerne til å svare på spørreskjemaet, som dessuten var oversatt til urdu, punjabi og engelsk. Vi fant ingen signifikant korrelasjon (Spearman) mellom de to målemetodene. Selvrapportert fysisk aktivitet var ikke signifikant korrelert med: alder, BMI, livvidde, $\mathrm{HbA1c}$, fastende og '2-timers glukose', fastende insulin, C-peptid, sittende systolisk- og diastolisk blodtrykk, totalkolesterol, LDL-kolesterol og triglyserider. På den annen side fant vi en invers relasjon mellom objektivt målt fysisk aktivitet og nevnte variabler. Sammenhengene holdt seg ved aldersjustering (lineær regresjon). Deltakere med selvrapportert god fysisk form hadde lavere BMI, livvidde, serum insulin, triglyserider og diastolisk blodtrykk. Resultatene tyder på at selvrapportering av fysisk aktivitet ikke alltid gir god nok opplysning til å bedømme graden av fysisk aktivitet, slik det ble funnet ved å bruke spørreskjemaet IPAQ på dette utvalget av innvandrerkvinner. Objektiv måling av energiomsetning kan synes nødvendig for å få gode estimater på fysisk aktivitet og dens gunstige helseeffekter.
\end{abstract}

\section{Hjellset VT, Høstmark AT. Is self-reported physical activity suitable for studying health effects of light physical activity? Nor J Epidemiol 2011; 20 (2): 135-142.}

\section{ENGLISH SUMMARY}

Physical activity can reduce the risk of many chronic diseases, and may be estimated using questionnaires, or measured objectively. In a group of Pakistani immigrant women living in Oslo, Norway, we found no significant correlations between use of the self report International Physical Activity Questionnaire (IPAQ) and objectively measured physical activity as assessed using the accelerometer SenseWear Armband. To ensure that the women understood the questions, the questionnaire had been translated to urdu and punjabi, and interpreters from Pakistan and India helped them in filling in IPAQ. There was an inverse relationship between objectively measured physical activity and age, BMI, waist circumference, HbAlc, fasting and 2-h glucose value, fasting insulin and C-peptide, systolic- and diastolic blood pressure (sitting), total cholesterol, LDL cholesterol and triglycerides, persisting after adjustment for age. Participants reporting good physical fitness had lower BMI, waist circumference, serum insulin, triglycerides and diastolic blood pressure as compared with those reporting bad fitness. The results suggest that self reporting may not be appropriate to evaluate the degree of physical activity, as shown in this group of immigrant women when using the International Physical Activity Questionnaire. An objective measure of energy expenditure seems to be necessary to obtain good estimates of physical activity and its beneficial health effects.

\section{INNLEDNING}

Regelmessig fysisk aktivitet er anbefalt som en del av livsstilen. Det er godt dokumentert at økt fysisk aktivitet kan redusere risikoen for metabolsk syndrom, type 2 diabetes (T2D), hjerte- og karsykdommer (HKS), enkelte typer kreft, ha en gunstig effekt på ulike typer av subjektive helseplager, og gi velvære (1). På den annen side øker fysisk inaktivitet (2-6) risikoen for metabolsk syndrom, T2D og HKS (7-11).

Det er økende holdepunkter for at også fysisk akti- vitet av lav til moderat intensitet har positive helseeffekter, spesielt hos de som fra før har vært svært lite fysisk aktive. Den nåværende anbefalingen for å fremme og opprettholde helse hos friske voksne er minst 30 minutter aerob fysisk aktivitet fem dager i uken $(4,12$, $13)$, eller flere økter av moderat intens fysisk aktivitet på de fleste, helst alle dager i uken $(4,14)$. Ny kunnskap tyder imidlertid på at selv korte perioder med meget lett fysisk aktivitet kan bedre helsen. US Department of Health and Human Services (1999) fremholder betydelige helseeffekter av moderat mengde fysisk 
aktivitet på de fleste, om ikke alle dager i uken, noe som er i tråd med de norske anbefalingene (15).

For å kunne iverksette og tilrettelegge for en helsefremmende livsstil, er det nødvendig å ha hensiktsmessige mål på eksempelvis røyking, kosthold og fysisk aktivitet. En persons fysiske form kan objektivt måles på tredemølle som $\mathrm{V}_{\mathrm{O} 2 \max }(16)$, som er et resultat av genetikk, alder og trening (17). Måling av fysisk aktivitet på befolkningsnivå er imidlertid vanskelig. Helseeffekter av fysisk aktivitet kan bedømmes på flere måter, og det finnes ingen "gullstandard". Både eksponerings- og utfallsvariabler må defineres nærmere. Eksponering for fysisk aktivitet kan eksempelvis relateres til type, intensitet, varighet og frekvens. På den annen side kan det være vesentlige forskjeller på fysisk aktivitet som fremmer det maksimale oksygenopptaket, og fysisk aktivitet som kan stabilisere blodsukkerkonsentrasjonen, optimalisere blodfettprofilen, bedre insulinfølsomheten og forebygge T2D. Det er vist at både utholdenhets- og styrketrening kan redusere postprandial økning i blodsukker og plasmainsulin, både hos friske mennesker og hos personer med T2D (18-21).

Som nevnt er det viktig å skille mellom fysisk aktivitet for å fremme helsen, og fysisk aktivitet som gir økt prestasjonsevne (22). Derfor er det utviklet ulike instrumenter for å kunne måle de ulike dimensjonene av fysisk aktivitet. Vanligst er spørreskjemaer, men også objektive målinger benyttes (23). Så langt synes det ikke å være noen "gullstandard" som dekker alle de ulike aspektene av fysisk aktivitet, i hvert fall ikke i intervensjonsstudier ute $\mathrm{i}$ felten. Objektive målinger av fysisk aktivitet inkluderer direkte og indirekte kalorimetri, med mekaniske eller elektroniske instrumenter som SenseWear Armband (24), eller forskjellige fysiologiske tiltak, blant annet bruk av tredemølle. Vanligst er imidlertid selvrapportering, enten i form av spørreskjemaer eller som aktivitetsdagbøker. Også observasjoner av fysisk aktivitet har vært benyttet. Hver av disse metodene har sine fordeler, men kan også ha begrensninger, alt avhengig av situasjonen og den aktuelle befolkningen som blir undersøkt. Ved måling av fysisk aktivitet er det viktig å inkludere fysisk aktivitet som er knyttet til transport, fri lek, arbeid og fritidsaktiviteter, og fysisk aktivitet ved hus- og hagearbeid.

Objektiv og presis måling av energiforbruk under fysisk aktivitet er mulig i et laboratorium. Ofte er avanserte metoder nødvendig. Den dobbelt merkete vannteknikken (DLW) er en isotopmetode for å beregne det totale daglige energiforbruket. På grunn av behov for avansert måleutstyr og store utgiftene, er det få studier der DLW har vært brukt rutinemessig. Men DLW kan tjene som standard for å validere andre målemetoder til å anslå det totale daglige energiforbruket over lengre tidsperioder (25). Akselerometere, som for eksempel SenseWear Armband, brukes også for å måle det totale energiforbruket (24).

Nyere norske data tyder på at selv lett fysisk aktivitet utført like etter et karbohydratrikt måltid har sterkt dempende effekt på blodsukkerstigningen (26-28). Ja, selv en rolig gå-tur etter karbohydratinntak kan redusere postprandial blodglukoseøkning i samme grad som legemidlet acarbose (som forsinker karbohydratfordøyelsen) (28). Siden de høyeste blodsukkerverdiene i døgnet kommer de første 2 timene etter karbohydratrike måltider, er det grunn til å anta at regelmessig, lett fysisk aktivitet etter slike måltider kan redusere den glykemiske belastningen. Disse resultatene føyer seg til rekken av velkjente gunstige effekter av fysisk aktivitet, slike som bedret kroppssammensetning, redusert fastende blodglukosekonsentrasjon, og økt insulinfølsomhet med oppregulering av glukosetransportører (glut 4) (29,30). Gåtur etter fettinntak kan også redusere den påfølgende triglyseridøkningen (31) og redusere blodtrykket.

Det er således gode holdepunkter for at selv lett fysisk aktivitet kan ha positive helseeffekter, både akutte og varige. Som nevnt benyttes gjerne spørreskjemaer for å undersøke graden av fysisk aktivitet i befolkningsgrupper. Dette reiser spørsmålet om selvrapportering gir tilstrekkelig grunnlag for å fange opp også lett fysisk aktivitet som kan ha positive helseeffekter. Spesielt er dette en aktuell problemstilling blant grupper av innvandrere, pga. både språklige og kulturtelle forhold. Innvandrere fra Sør-Asia til vestlige land har en økt risiko for å utvikle T2D (32-35). For å belyse problemstillingen vil vi i denne artikkelen omtale noen resultater fra en nylig gjennomført norsk studie blant pakistanske innvandrerkvinner bosatt i Oslo. Vi stiller følgende spørsmål: 1) Er det sammenheng mellom selvrapportert og objektivt registrert fysisk aktivitet? 2) Er det sammenheng mellom fysisk aktivitet, målt på begge måter, og noen andre helsevariabler?

\section{MeTODE}

Datagrunnlaget i denne studien er basert på InnvaDiab-DEPLAN-studien blant 198 innvandrerkvinner fra Pakistan (36). Dette var en randomisert, kontrollert intervensjonsstudie utført i 2006-2008 i en bydel i Oslo (Søndre Nordstrand).

\section{Deltakere}

Alle deltakerne var kvinner i alderen $\geq 25$ år, født $i$ Pakistan eller i Norge. Begge foreldrene var pakistanske. Eksklusjonskriterier var graviditet, T2D, HKS og/eller en nær slektning som allerede var inkludert i prosjektet. Basert på tidligere erfaringer fra arbeid med sørasiater (37) ble det valgt en bred rekrutteringstilnærming. Sentrale medlemmer i det pakistanske miljøet ble konsultert for å gi bistand i studien. Det ble holdt et innlegg i en moské, og kvinnenes egne nettverk ble benyttet. Inklusjonskriteriene ble satt så bredt som mulig. En vitenskapelig assistent som kunne urdu hadde ansvaret for rekruttering. I alt 245 kvinner ble invitert til studien. Av disse deltok 198. Imidlertid er det bare 86 kvinner vi har objektive data på fysisk aktivitet (målt med SenseWear Armband). Resultatene i 
denne artikkelen begrenser seg derfor til disse 86. Studien ble gjennomført på den lokale helsestasjonen.

Ved inklusjon og etter intervensjonen gjennomgikk alle deltakerne en omfattende kartlegging. Etter 12timers faste over natten ble det tatt venøse blodprøver, og utført en standardisert oral glukosetoleransetest (OGTT). I løpet av de to timene deltakerne gjennomførte OGTT svarte de på spørsmålene i et spørreskjema, $i$ en intervjusituasjon med prosjektmedarbeidere fra Pakistan og India. Alle intervjuene foregikk på det språket deltakerne foretrakk (urdu, punjabi eller engelsk). Spørreskjemaene dreide seg om fysisk aktivitet, helse, mestringsstrategier, muskel- og skjelettplager, samt og kosthold. To til sju dager etter inklusjon utførte deltakerne en maksimal pulstest på en tredemølle, der aktivitetsnivået ble vurdert på Borg-skala (38). I tillegg ble maksimal hjertefrekvens målt på tredemølle etter "Ramt" metode (25). Borg-skala ble brukt som subjektivt mål på utmattelse i løpet av tredemølletesten.

\section{Måling av fysisk aktivitet}

\section{Spørreundersøkelse}

Deltakerne ble bedt om å besvare spørsmål om fysisk aktivitet, ved bruk av en kortversjon av International Physical Activity Questionnaire (IPAQ) (39). IPAQ er et skjema som kartlegger både fysisk aktivitet og inaktivitet, og det dekker de fire hovedarenaene for fysisk aktivitet (arbeid, fritid, transport, hus/hjem/hage). Skjemaet omfatter også holdninger til fysisk aktivitet, og vurderinger av hvordan fysisk aktivitet påvirker helsen, men resultater fra denne delen av skjemaet er ikke gjengitt i artikkelen. Spørreskjemaet har gitt tilfredsstillende reliabilitet og validitet for nasjonale og regionale prevalensstudier i fjorten forskjellige land fra hele verden, fra Sverige til Guatemala, og omfatter både urbane og rurale områder (39). Deltakerne i vår undersøkelse har i liten grad vært aktive i arbeidslivet, og de har liten tradisjon for å drive fysisk aktivitet $\mathrm{i}$ fritiden, både organisert og uorganisert. Det har derfor ikke vært mulig å gi et pålitelig estimat på hvor mange timer denne gruppen har vært fysisk aktive. Det synes derimot enklere å få data på hvor mange timer de har vært sittende. Spørsmål som går på vurdering av egen form og aktivitetsgrad synes også å gi rimelige svar. Sentrale spørsmål for den aktuelle problemstillingen er gitt $i$ Tabell 2. I tillegg ble det registrert sosio-demografiske data (alder, år bodde i Norge, antall år i utdanning, både i Pakistan og Norge, samt om de kunne norsk). Norskkunnskaper ble omkodet fra 5 svarkategorier til bare 2, dvs. "dårlig" (ganske dårlig - dårlig) og "god" (gjennomsnittlig - veldig bra).

Spørreskjemaet ble oversatt til urdu, punjabi og engelsk, og kommunikasjonen med deltakerne skjedde via tolk. Alle intervjuerne var flerspråklige. De kjente godt både norsk og pakistansk kultur, og det var lagt spesiell vekt på oversettelsen av spørsmålene om fysisk aktivitet. Også en tredje person, som kunne alle språkene, var til stede ved utfyllingen.
Objektiv registrering med SenseWear Armband

Ved inkludering ble SenseWear Armband montert på høyre overarm. Med dette apparatet er det mulig å få en objektiv registrering av antall skritt, intensitet og totalt energiforbruk. Den oppgir også energiforbruk som skyldes fysisk aktivitet. Denne metoden er validert mot dobbelt merket vann (24). Bruk av SenseWear Armband krever assistanse av kompetente fagfolk, og er tidkrevende. Dessverre hadde vi ikke kapasitet til å utføre målingene på mer enn 86 av deltakerne (tilfeldig utplukket). Energiforbruket ble beregnet ved hjelp av formler utviklet av produsenten. Deltakerne fikk beskjed om å bære armbåndet i 10 dager, unntatt når de skulle dusje eller bade. Bare dager med minst 20 timers opptak ble inkludert i analysene. Resultatene i denne artikkelen begrenser seg derfor til de 86 kvinnene som brukte SenseWear Armband.

\section{Resultater}

\section{Bakgrunnsdata}

Ved inklusjon var gjennomsnittsalderen 39,8 år (Tabell 1). Deltakerne hadde bodd i Norge ca 19 år, hadde 3-4 barn (gjennomsnitt 3,3), ca 9 års utdanning (spredning fra 0-19 år) og om lag 80\% hadde dårlige norskkunnskaper. Det var svært høy forekomst av overvekt $(32,6 \%)$ og fedme $(59,3 \%)$, og en gjennomsnittlig livvidde på $95 \mathrm{~cm}$. Bare syv $(8,1 \%)$ av deltakerne hadde normal BMI, og seks $(7,1 \%)$ hadde normal livvidde. Det var 38,8\% $(n=33)$ av deltagerne som fylte kravet til metabolsk syndrom, og $14 \%(n=12)$ hadde T2D.

\section{Registrering av fysisk aktivitet og fysisk form}

a) Data innhentet ved spørreskjema

Syttini \% $(n=68)$ av deltagerne rapporterte at de sitter mindre en 4 timer daglig (Tabell 2). Ved bruk av stadiemodellen for endring rapporterer $40 \%(n=44)$ at de

Tabell 1. Bakgrunnsdata for utvalget $(n=86)$.

\begin{tabular}{lc}
\hline Variabler & Gjennomsnitt (SD) \\
\hline Alder (år) & $39,8(8,3)$ \\
År i Norge & $18,7(7,9)$ \\
Antall barn & $3,3(1,6)$ \\
Norskkunnskaper & - \\
$\quad$ Dårlige (\%) & 81,4 \\
$\quad$ Gode til svært gode (\%) & 18,6 \\
Utdanning (år) & $8,8(4,3)$ \\
Livvidde (cm) & $94,5(13,3)$ \\
BMI (kg/m $\left.{ }^{2}\right)$ & $29,3(6,2)$ \\
\% med overvekt (BMI $\geq 23)$ & 32,6 \\
\% med fedme (BMI $\geq 27)$ & 59,3 \\
\% med metabolsk syndrom & 42,6 \\
\% med Type 2 diabetes & 14,0 \\
\hline
\end{tabular}

${ }^{1}$ Metabolsk syndrom er her definert som livvidde $\geq 80$ $\mathrm{cm}$, pluss minst to av følgende krav: serum triglyserider $\geq 1,7 \mathrm{mmol} / \mathrm{L}$, HDL-kolesterol $<1,29 \mathrm{mmol} / \mathrm{L}$, systolisk blodtrykk $\geq 130 \mathrm{mmHg}$ eller diastolisk blodtrykk $\geq 85$ $\mathrm{mmHg}$, fastende glukose $\geq 5,6 \mathrm{mmol} / \mathrm{L} \mathrm{(3)}$. 
Tabell 2. Fordeling av selvrapportert fysisk aktivitet og fysisk form.

\begin{tabular}{llrc}
\hline Variablene & Svaralternativer & $\mathrm{n}$ & $\%$ \\
\hline Hvor mye tid bruker du & $<15$ & 0 & 0 \\
på å sitte hver dag (min) & $15-29$ & 0 & \multicolumn{1}{c}{0} \\
& $30-59$ & 2 & 2,3 \\
& $60-119$ & 23 & 26,7 \\
& $120-239$ & 43 & 50,0 \\
& $>4$ timer & 18 & 20,9 \\
& Ikke FA, ingen planer om endring & 11 & 12,8 \\
Stadiemodellen brukt i & Ikke FA, men jeg vil bli det i fremtiden & 39 & 45,3 \\
selvvurdert fysisk aktivi- & 11 & 12,8 \\
tet (FA) de neste 6 mnd & Jeg prøver å bli interessert i FA & 12 & 14,0 \\
& Jeg er interessert i å bli FA & 13 & 15,1 \\
& Jeg er allerede aktiv & 13 & 15,1 \\
Stadiemodellen brukt på & Ikke FA, ingen planer om endring & 34 & 39,5 \\
nåværende fysisk aktivi- & Ikke FA, planlegger å bli mer FA i løpet av 6 mnd & 15 & 17,4 \\
tetsnivå når fysisk aktivi- & Litt FA, men ikke regelmessig & 10 & 11,6 \\
tet er definert & & 13 & 15,1 \\
& Regelmessig FA siste 6 mnd & 7 & 8,1 \\
Selvvurdert fysisk form & Regelmessig FA i lang tid & 10 & 11,6 \\
& Ekstremt god & 33 & 38,4 \\
& Svært god & 27 & 31,4 \\
& God & 9 & 10,5 \\
\hline & Dårlig & Svært dårlig &
\end{tabular}

${ }^{1}$ Fysisk aktivitet $(\mathrm{FA})=30$ min per dag, eller 10 min 3 ganger per dag 4-5 dager i uken, eller minimum 4 timer per uke.

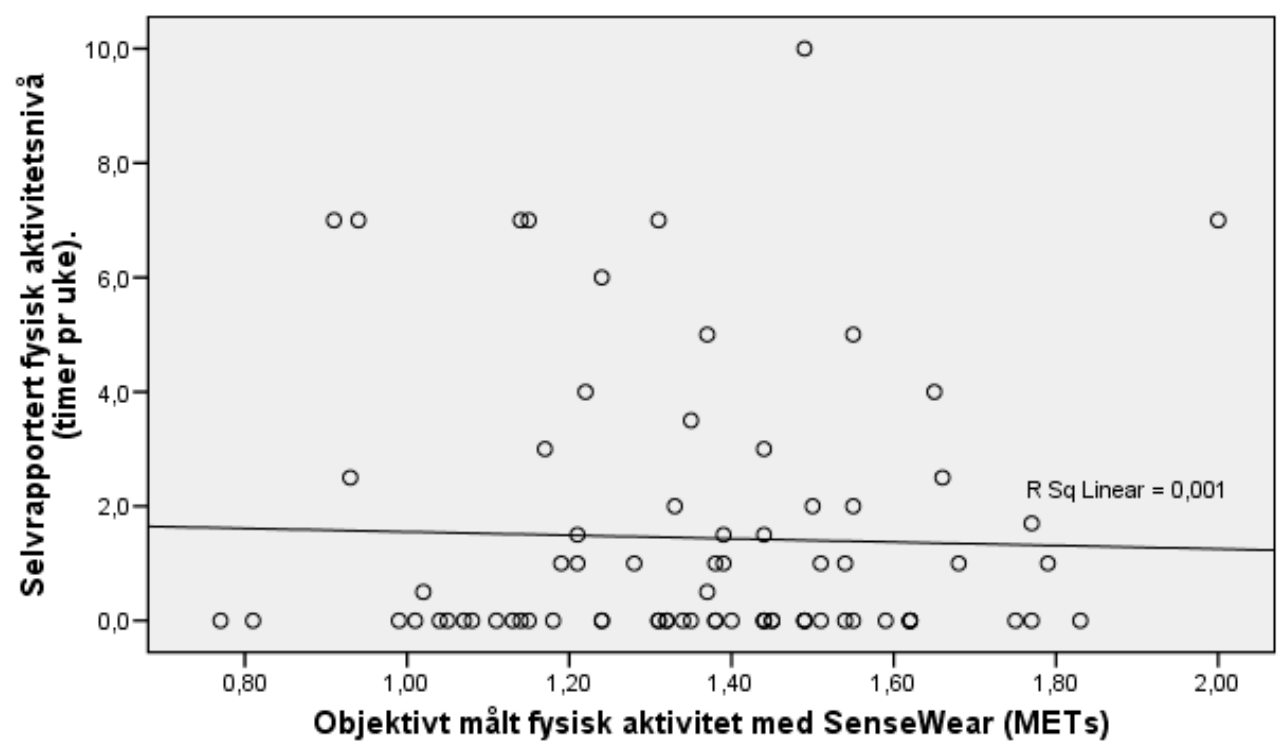

Figur 1. Scatter-plot for objektivt målt fysisk aktivitet (dvs. med SenseWear Armband) mot selvrapportert fysisk aktivitet (spørreskjema).

ikke ønsker å drive med fysisk aktivitet i løpet av de neste $6 \mathrm{mnd} .71 \%(\mathrm{n}=61)$ sier at de for tiden ikke har regelmessig fysisk aktivitet. Femtiåtte \% $(\mathrm{n}=50)$ rapporterer at de har god fysisk form.

b) Objektiv registrering med SenseWear Armband Målinger gjort med SenseWear Armband viser at det gjennomsnittlig var et lavt totalt energiforbruk i hele gruppen, $2298 \mathrm{kcal} / 24 \mathrm{t}( \pm \mathrm{SD} 3928)$ (Tabell 3). Ener- giomsetningen per 24 timer målt i METs var 1,36 $( \pm 0,24)$. Gjennomsnittlig antall skritt for gruppen var ca 10000 ( \pm 3928$)$.

Er det sammenheng mellom fysisk aktivitet funnet ved spørreskjema og Armband-resultatene?

Vi fant ingen sammenheng mellom fysisk aktivitet målt med SenseWear Armband og selvrapportert fysisk aktivitet (figur 1). 
Tabell 3. Daglig energiforbruk og antall skritt, registrert med SenseWear Armband $(n=86)$, som objektivt mål på fysisk aktivitet.

\begin{tabular}{|c|c|}
\hline Totalt energiforbruk (Kcal/24 t) & $2298(301)^{1}$ \\
\hline Energiforbruk som skyldes fysisk aktivitet (Kcal/24 t) & 357 (314) \\
\hline $\mathrm{METs}^{2}$ & $1,36(0,24)$ \\
\hline Antall skritt/24 t & $9822(3928)$ \\
\hline
\end{tabular}

${ }^{1}$ Gjennomsnitt, med standardavvik i parentes. ${ }^{2}$ Metabolic Equivalent of Task, dvs. en måleenhet for energiforbruk ved fysisk aktivitet [48]. For eksempel vil moderat fysisk aktivitet kreve tre til seks ganger så mye energi som energibehovet i hvile, dvs. 3-6 METs.

Tabell 4. Korrelasjoner (Spearman) mellom fysisk aktivitet (selvrapportert, og registrert med SenseWear Armband) og andre helsevariabler.

\begin{tabular}{lcc}
\hline Variabler & $\begin{array}{c}\text { Selvrapportert fysisk } \\
\text { aktivitet }\end{array}$ & $\begin{array}{c}\text { Objektivt målt fysisk } \\
\text { aktivitet }^{1}\end{array}$ \\
\hline Alder &, 013 &,$- 363^{*}$ \\
BMI &,- 119 &,$- 635^{*}$ \\
Omliv &,- 147 &,$- 556^{*}$ \\
HbA1c &,- 098 &,$- 353^{*}$ \\
Fast gl &,- 080 &,$- 262^{*}$ \\
2-t gl &,- 016 &,$- 331^{*}$ \\
Insulin &,- 122 &,$- 474^{*}$ \\
C-peptid &,- 112 &,$- 446^{*}$ \\
Syst BT &,- 111 &,$- 458^{*}$ \\
Diast BT &,- 156 &,$- 493^{*}$ \\
TC &, 066 &,$- 326^{*}$ \\
HDL &, 059 &, 093 \\
LDL &, 094 &,$- 287^{*}$ \\
TG &,- 077 &,$- 321^{*}$ \\
\hline
\end{tabular}

${ }^{1}$ Fysisk aktivitet registrert med SenseWear Armband, Omliv $=$ omkrets liv, Fast $\mathrm{gl}=$ fasteverdi for blodglukose, 2 -t $\mathrm{gl}=$

blodglukose 2 timer etter inntak av 75 g glukose, Syst BT $=$ sittende systolisk blodtrykk, Diast BT $=$ sittende diastolisk blodtrykk TC $=$ totalkolesterol, $\mathrm{HDL}=$ high density lipoprotein kolesterol, $\mathrm{LDL}=$ low density lipoprotein kolesterol, $\mathrm{TG}=$ triglyserider.

$* \mathrm{P}<0.05$

\section{Er det sammenheng mellom fysisk aktivitet og andre helserelaterte variabler?}

Selvrapportert fysisk aktivitet og fysisk form

Som vist i Tabell 4 fant vi ingen signifikant korrelasjon mellom selvrapportert fysisk aktivitet og følgende variabler: alder, BMI, livvidde, $\mathrm{HbA} 1 \mathrm{c}$, fastende og 2timers glukose, fastende insulin og C-peptid, sittende systolisk- og diastolisk blodtrykk, total kolesterol, LDL-kolesterol og triglyserider. Imidlertid fant vi at de som rapporterte dårlig fysisk form hadde høyere BMI $(p<0,001)$, livvidde $(p<0,001)$, serum insulin $(p=0,044)$, triglyserider $(\mathrm{p}=0,003), \mathrm{og}$ sittende diastolisk blodtrykk $(p=0,013)$ enn de som rapporterte god fysisk form (resultatene er ikke oppført i tabell).

\section{Objektivt registrert fysisk aktivitet}

Det var negativ korrelasjon mellom objektivt registrert fysisk aktivitet og: alder, BMI, livvidde, HbA1c, fastende og 2-timers glukose, fastende insulin og Cpeptid, sittende systolisk- og diastolisk blodtrykk, total kolesterol, LDL-kolesterol og triglyserider (Tabell 4).

Ved lineær regresjon og justert for alder (Tabell 5) fant vi signifikant sammenheng mellom objektivt målt fysisk aktivitet (SenseWear Armband), og totalkolesterol, systolisk blodtrykk (sittende), insulin, C-peptid, med fastende og 2timers blodglukose.

For formålet med denne artikkelen har vi bare tatt med korrelasjoner med selvrapportert og objektivt målt fysisk aktivitet.

\section{DISKUSJON}

I dette utvalget av innvandrerkvinner fant vi at selvrapportert fysisk aktivitet ikke samsvarer med fysisk aktivitet målt på en objektiv måte. Dette funnet kan bety at selvrapportering vil være av begrenset verdi når man skal belyse helsevirkninger av fysisk aktivitet hos innvandrerkvinner, og at det må benyttes objektive mål.

Siden flere studier viser at fysisk aktivitet virker positivt på en rekke helsevariabler (40), skulle vi også i denne studien forvente å finne en sammenheng mellom fysisk aktivitet og for eksempel blodtrykk, eller serumlipider, eller livvidde. I tråd med dette fant vi mange signifikante sammenhenger mellom objektivt målt fysisk aktivitet og en lang rekke andre risikofaktorer for hjerte- og karsykdommer og diabetes. Det forhold at ingen slike korrelasjoner ble påvist når fysisk aktivitet var selvrapportert tyder på at selvrapportering ikke fanger opp forskjeller i fysisk aktivitet på en god nok måte. Imidlertid fant vi at de som rapporterte dårlig fysisk form hadde høyere BMI, livvidde, serum insulin, triglyserider, og sittende diastolisk

Tabell 5. Lineær regresjon for å undersøke sammenheng mellom objektivt målt fysisk aktivitet (uavhengig variabel) og ulike helsevariabler (avhengige variabler).

\begin{tabular}{lcccccc}
\hline & \multicolumn{3}{c}{ Uten justering } & \multicolumn{3}{c}{ Justert for alder } \\
\cline { 2 - 7 } Avhengige variabler & $\beta$ koeffisient & $\mathrm{t}$ & $\mathrm{p}$ & $\beta$ koeffisient & $\mathrm{t}$ & $\mathrm{p}$ \\
\hline Totalkolesterol &,- 306 & $-2,9$ & 0,005 &,- 244 & $-2,2$ & 0,028 \\
Systolisk blodtrykk &,- 405 & $-4,1$ & $<0,001$ &,- 326 & $-3,3$ & 0,002 \\
Insulin &,- 471 & $-4,7$ & $<0,001$ &,- 512 & $-5,1$ & $<0,001$ \\
C-peptid &,- 440 & $-4,5$ & $<0,001$ &,- 426 & $-4,1$ & $<0,001$ \\
Fastende blodglukose & $-0,058$ & $-0,5$ & 0,598 & 0,001 & $<-0,1$ & 0,993 \\
2-timers blodglukose & $-2,265$ & $-2,5$ & 0,014 & $-0,242$ & $-2,2$ & 0,032 \\
\hline
\end{tabular}


blodtrykk enn de som rapporterte god fysisk form. Det ser derfor ut til at selvrapportert fysisk form kan være et bedre mål på gunstige helseeffekter enn det som fremkommer ved selvrapportert fysisk aktivitet. Det er også interessant i denne sammenheng at blodglukose to timer etter inntatt glukose var signifikant lavere hos de med selvrapportert god fysisk form enn hos de med dårlig fysisk form, mens det ikke var noen slik forskjell i fastende blodglukose. Dette kan kanskje også tolkes slik at blodglukoseverdien 2 timer etter glukoseinntak avspeiler den fysiske formen bedre enn fasteverdien.

Manglende samsvar mellom de to målemetodene for fysisk aktivitet kan kanskje tilskrives at den undersøkte befolkningsgruppen sannsynligvis har svært lav fysisk aktivitet, og at perioder med meget lett fysisk aktivitet ikke vil bli registrert i en spørreundersøkelse. Eksempelvis vil det å bevege seg i huset under matlaging og annet lett husarbeid bli registrert med akselerometer, men sannsynligvis ikke bli tatt med hvis det ikke eksplisitt spørres om denne typen fysisk aktivitet. En annen forklaring kan være at spørreskjemaet ikke er presist nok til å å fange opp lett fysisk aktivitet og/eller at deltakerne ikke har forstått det som etterspørres.

Til tross for høy forekomst av fedme og metabolsk syndrom hadde deltakerne lavt til normalt totalkolesterol, HDL-kolesterol, LDL-kolesterol og blodtrykk og høyt antall skritt ved objektive målinger, noe som er i tråd med deltakernes subjektive rapport av få timer i ro i løpet av et døgn. Imidlertid var det et lavt totalt energiforbruk registrert med armbåndet. Disse funn reiser spørsmålet om det langvarige, lette aktivitetsnivået kanskje bidro til å senke blodtrykk og serumkolesterol, og påvirke andre helsevariabler, noe regresjonsanalysene kunne tolkes i retning av. Det er tidligere vist at selv en rolig gåtur etter karbohydratinntak motvirker blodsukkerøkningen $(26,28,41)$.

Innvandrere fra Sør-Asia til vestlige land har en økt risiko for å utvikle T2D $(7,32)$. I en studie fra Oslo, var den aldersjusterte forekomsten av T2D blant innvandrerkvinner fra Sør-Asia 27,5\% i aldersgruppen 40-59 år, med en odds ratio på 11,0 sammenlignet med vestlige kvinner (42). I tillegg til mulige genetiske faktorer, kan den økte risikoen for T2D forklares med en usunn livsstil, både med hensyn til kosthold (43), lave nivåer av fysisk aktivitet (5), og psykososiale faktorer (44-46).

Resultater fra InnvaDiab-studien viser at det i Norge også er høy forekomst av metabolsk syndrom blant innvandrerkvinner fra Pakistan (36). En person med metabolsk syndrom har flere risikofaktorer for diabetes og hjerte-karsykdommer, inkludert sentral fedme (økt livvidde), forhøyede nivåer av blodglukose, triglyserider og blodtrykk, samt redusert HDL-kolesterol (47, 48). Personer med metabolsk syndrom har høy risiko for å utvikle T2D (32). Det er kjent at fysisk aktivitet øker insulinfølsomheten (49). Dette kan være en viktig faktor $\mathrm{i}$ forebygging av T2D, spesielt i grupper med økt risiko. I samsvar med dette fant vi også i denne studien at objektivt målt fysisk aktivitet var inverst korrelert med både insulin og C-peptid.

Spørreskjema med selvrapportering av fysisk aktivitet er mye brukt fordi det er lett å få data fra et stort antall mennesker til lave kostnader (23), men spørreundersøkelser har sine begrensninger. I starten var spørreskjemaer om fysisk aktivitet beregnet på fysisk aktivitet - mønsteret hos menn, for eksempel hardt fysisk arbeid og trening, og idrett med intens fysisk aktivitet. Kanskje skulle det utarbeides spesielle skjemaer til innvandrerkvinner med ulik kulturbakgrunn? Vanskeligheter med å huske kan være et problem, ettersom fysisk aktivitet for mange mennesker vil variere fra dag til dag, og fra årstid til årstid. Det er ofte vanskelig, tidkrevende eller oppfattes som kjedelig å skulle detaljrapportere intensitet og varighet av fysisk aktivitet den siste uken, eller i en "vanlig uke". Upresis rapportering vil redusere påliteligheten til de innsamlede dataene. Denne undersøkelsen kan tyde på at det ikke er uproblematisk å benytte en spørreundersøkelse til å avdekke om det er sammenheng mellom nivå av fysisk aktivitet og andre helsevariabler.

For å sikre god kommunikasjon ble spørreskjemaet oversatt til urdu, punjabi og engelsk, og det ble brukt tolk. Alle intervjuerne var flerspråklige. De kjente godt både norsk og pakistansk kultur, og det var lagt spesiell vekt på korrekt oversettelse av spørsmålene om fysisk aktivitet. Også en tredje person, som kunne alle språkene, var til stede ved utfyllingen av skjemaene. På tross av dette vil det alltid eksistere muligheter for at det kan ha forekommet noen skjevheter i informasjonsflyten mellom intervjuer og respondentene. I Pakistan finnes eksempelvis ikke et eget ord for fysisk aktivitet, slik vi har på norsk. Dette begrepet ble spesielt godt forklart. Vi mener derfor at deltakerne forsto alle spørsmålene. Kvinnene i denne undersøkelsen var i liten grad i lønnet arbeid, og hadde ikke tradisjon for å drive fysisk aktivitet i fritiden. Vi fikk derfor inntrykk av at spørsmålet om hvor lenge de satt i ro i løpet av en dag, også ga informasjon tid om tid med fysisk aktivitet.

På basis av denne studien ser det ut til at selvrapportering knyttet til spørreskjemaer ikke gir god nok opplysning til å bedømme graden av fysisk aktivitet, i alle fall ikke $\mathrm{i}$ dette utvalget av innvandrerkvinner. Med et større utvalg og mer presise spørsmål kunne en kanskje oppnå bedre data. Likevel er det vår oppfatning at objektive mål på energiomsetning er nødvendig for å få gode estimater på fysisk aktivitet og dens gunstige helseeffekter. 


\section{REFERANSER}

1. Physical Activity Guidelines Advisory Committee. Physical Activity Guidelines Advisory Committee Report. Washington, DC: U.S.Department of Health and Human Services; 2008.

2. Albright A, Franz M, Hornsby G, Kriska A, Marrero D, Ullrich I, et al. American College of Sports Medicine position stand. Exercise and type 2 diabetes. Med Sci Sports Exerc 2000; 32 (7): 1345-60.

3. Tuomilehto J, Lindstrom J, Eriksson JG, Valle TT, Hamalainen H, Ilanne-Parikka P, et al. Prevention of type 2 diabetes mellitus by changes in lifestyle among subjects with impaired glucose tolerance. $N$ Engl $J$ Med 2001; 344 (18): 1343-50.

4. Pate RR, Pratt M, Blair SN, Haskell WL, Macera CA, Bouchard C, et al. Physical activity and public health A recommendation from the Centers for Disease Control and Prevention and the American College of Sports Medicine. JAMA 1995; 273 (5): $402-7$.

5. Blair SN, Kohl HW, Barlow CE, Paffenbarger RS, Gibbons LW, Macera CA. Changes in physical fitness and all-cause mortality - A prospective study of healthy and unhealthy men. JAMA 1995; 273 (14): 1093-8.

6. Sigal RJ, Kenny GP, Wasserman DH, Castaneda-Sceppa C. Physical activity/exercise and type 2 diabetes. Diabetes Care 2004; 27 (10): 2518-39.

7. King H, Rewers M. Diabetes in adults is now a Third World problem. The WHO Ad Hoc Diabetes Reporting Group. Bull World Health Organ 1991; 69 (6): 643-8.

8. Sullivan PW, Morrato EH, Ghushchyan V, Wyatt HR, Hill JO. Obesity, inactivity, and the prevalence of diabetes and diabetes-related cardiovascular comorbidities in the U.S., 2000-2002. Diabetes Care 2005; 28 (7): 1599-603.

9. Paffenbarger R. Physical exercise to reduce cardiovascular disease risk. Proc Nutr Soc 2000; 59 (3): 421-2.

10. Gill JM, Cooper AR. Physical activity and prevention of type 2 diabetes mellitus. Sports Med 2008; 38 (10): $807-24$.

11. Strasser B, Siebert U, Schobersberger W. Resistance training in the treatment of the metabolic syndrome: a systematic review and meta-analysis of the effect of resistance training on metabolic clustering in patients with abnormal glucose metabolism. Sports Med 2010; 40 (5): 397-415.

12. Hu G, Lindstrom J, Valle TT, Eriksson JG, Jousilahti P, Silventoinen K, et al. Physical activity, body mass index, and risk of type 2 diabetes in patients with normal or impaired glucose regulation. Arch Intern Med 2004; 164 (8): 892-6.

13. Duncan JJ, Gordon NF, Scott CB. Women walking for health and fitness - How much is enough. JAMA 1991; 266 (23): 3295-9.

14. O'Donovan G, Blazevich AJ, Boreham C, Cooper AR, Crank H, Ekelund U, et al. The ABC of Physical Activity for Health: a consensus statement from the British Association of Sport and Exercise Sciences. $J$ Sports Sci 2010; 28 (6): 573-91.

15. Sosial- og helsedirektoratet. Fysisk aktivitet og helse, anbefalinger. Sosial- og helsedirektoratet, avdeling for fysisk aktivitet; 2000.

16. American College of Sports Medicine. ACSM's guidelines for exercise testing and prescription. Baltimore: Lippincott Williams \& Wilkins; 2005.

17. Caspersen CJ, Powell KE, Christenson GM. Physical activity, exercise, and physical fitness: definitions and distinctions for health-related research. Public Health Rep 1985; 100 (2): 126-31.

18. Poehlman ET, Dvorak RV, DeNino WF, Brochu M, Ades PA. Effects of resistance training and endurance training on insulin sensitivity in nonobese, young women: a controlled randomized trial. J Clin Endocrinol Metab 2000; 85 (7): 2463-8.

19. Kang J, Robertson RJ, Hagberg JM, Kelley DE, Goss FL, DaSilva SG, et al. Effect of exercise intensity on glucose and insulin metabolism in obese individuals and obese NIDDM patients. Diabetes Care 1996; 19 (4): 341-9.

20. King DS, Baldus PJ, Sharp RL, Kesl LD, Feltmeyer TL, Riddle MS. Time course for exercise-induced alterations in insulin action and glucose tolerance in middle-aged people. $J$ Appl Physiol 1995; 78 (1): 17-22.

21. Andersen E, Høstmark AT. Effect of a single bout of resistance exercise on postprandial glucose and insulin response the next day in healthy, strength-trained men. J Strength Cond Res 2007; 21 (2): 487-91.

22. Shephard RJ, Bouchard C. Population evaluations of health related fitness from perceptions of physical activity and fitness. Can J Appl Physiol 1994; 19 (2): 151-73.

23. Sallis JF, Saelens BE. Assessment of physical activity by self-report: status, limitations, and future directions. Res Q Exerc Sport 2000; 71 (2 Suppl): 1-14.

24. St-Onge M, Mignault D, Allison DB, Rabasa-Lhoret R. Evaluation of a portable device to measure daily energy expenditure in free-living adults. Am J Clin Nutr 2007; 85 (3): 742-9.

25. McArdle WD, Katch FI, Katch VL. Exercise Physiology, energy, nutrition and human performance. Fifth edition ed. Lippincott Williams \& Wilkins; 2001. 
26. Høstmark AT, Ekeland GS, Beckstrom AC, Meen HD. Postprandial light physical activity blunts the blood glucose increase. Prev Med 2006; 42 (5): 369-71.

27. Aadland E, Høstmark AT. Very light physical activity after a meal blunts the rise in blood glucose and insulin. Open Nutrition Journal 2008; 2: 94-99.

28. Nygaard H, Tomten SE, Høstmark AT. Slow postmeal walking reduces postprandial glycemia in middle-aged women. Appl Physiol Nutr Metab 2009; 34 (6): 1087-92.

29. Vander A, Sherman J, Luciano D. Human Physiology. McGraw-Hill International Edition; 2001.

30. Marwick TH, Hordern MD, Miller T, Chyun DA, Bertoni AG, Blumenthal RS, et al. Exercise training for type 2 diabetes mellitus: impact on cardiovascular risk: a scientific statement from the American Heart Association. Circulation 2009; 119 (25): 3244-62.

31. Tsetsonis NV, Hardman AE, Mastana SS. Acute effects of exercise on postprandial lipemia: a comparative study in trained and untrained middle-aged women. Am J Clin Nutr 1997; 65 (2): 525-33.

32. IDF, Unwin N, Gan D, Mbanya J-C, Ramachandran A, Roglic G, et al. IDF Diabetes atlas, fourth edition. International Diabetes Federation; 2009.

33. International Diabetes Federation. Guideline for Management of postmeal glucose. 2007.

34. Ceriello A, Colagiuri S. International Diabetes Federation guideline for management of postmeal glucose: a review of recommendations. Diabet Med 2008; 25 (10): 1151-6.

35. World Health Organization, International Diabetes Federation. Definition and diagnosis of diabetes mellitus and intermediate hyperglycaemia. 2006.

36. Hjellset VT, Bjørge B, Eriksen HR, Høstmark AT. Risk factors for type 2 diabetes among female Pakistani immigrants: The InvaDiab-DEPLAN Study on Pakistani immigrant women living in Oslo, Norway. J Immigr Minor Health 2011; 13: 101-110.

37. Hussain-Gambles M, Leese B, Atkin K, Brown J, Mason S, Tovey P. Involving South Asian patients in clinical trials. Health Technol Assess 2004; 8 (42): iii, 1-iii109.

38. Borg GA. Psychophysical bases of perceived exertion. Med Sci Sports Exerc 1982; 14 (5): 377-81.

39. Craig CL, Marshall AL, Sjostrom M, Bauman AE, Booth ML, Ainsworth BE, et al. International physical activity questionnaire: 12-country reliability and validity. Med Sci Sports Exerc 2003; 35 (8): 1381-95.

40. Blair SN, Kampert JB, Kohl HW, Barlow CE, Macera CA, Paffenbarger RS, et al. Influences of cardiorespiratory fitness and other precursors on cardiovascular disease and all-cause mortality in men and women. JAMA 1996; 276 (3): 205-10.

41. Aadland E, Høstmark AT. Very light physical activity after a meal blunts the rise in blood glucose and insulin. Open Nutrition Journal 2008; 2: 94-9.

42. Jenum AK, Holme I, Graff-Iversen S, Birkeland KI. Ethnicity and sex are strong determinants of diabetes in an urban Western society: implications for prevention. Diabetologia 2005; 48 (3): 435-9.

43. Wandel M. Nutrition-related diseases and dietary change among Third World immigrants in northern Europe. Nutr Health 1993; 9 (2): 117-33.

44. Dalgard OS, Thapa SB, Hauff E, McCubbin M, Syed HR. Immigration, lack of control and psychological distress: findings from the Oslo Health Study. Scand J Psychol 2006; 47 (6): 551-8.

45. Syed HR, Dalgard OS, Hussain A, Dalen I, Claussen B, Ahlberg NL. Inequalities in health: a comparative study between ethnic Norwegians and Pakistanis in Oslo, Norway. Int J Equity Health 2006; 5: 7.

46. Hjellset VT, Ihlebaek C, Bjørge B, Eriksen HR, Høstmark AT. Health-related quality of life, subjective health complaints, psychological distress and coping in Pakistani immigrant women with and without The Metabolic Syndrome. The InnvaDiab-DEPLAN study on Pakistani immigrant women living in Oslo, Norway. J Immigr Minor Health, epub ahead of print, 2010.

47. International Diabetes Federation. The IDF consensus worldwide definition of the metabolic syndrome. 9-62009.

48. Miranda PJ, DeFronzo RA, Califf RM, Guyton JR. Metabolic syndrome: definition, pathophysiology, and mechanisms. Am Heart J 2005; 149 (1): 33-45.

49. DeFronzo RA, Sherwin RS, Kraemer N. Effect of physical training on insulin action in obesity. Diabetes 1987; 36 (12): 1379-85. 